\title{
Hudba jako jeden z možných aspektů preevangelizace
}

\section{Karel Ochozka}

V předkládaném príspěvku autor nahlíži na hudbu jako na jednu z možných forem preevangelizace. Termín hudba je, v souvislosti se zaměřením textu, použiván významově v širším slova smyslu. Jedná se o tzv. náboženskou, duchovní hudbu (tj. hudbu inspirovanou náboženstvím - Biblí, úctou k Bohu a svatým, liturgií, životem církve) a nejen o hudbu liturgickou, sakrální či církevní. Do popředí je, v kontextu s tématem, kladeno především využití hudby při poslechových činnostech. Dále je poukázáno na estetický prvek $v$ hudbě, který může přispívat k vnímání a využití hudby. Téma je zasazeno do kontextu církevních dokumentů a koresponduje s vnímáním a funkcí hudby v církvi.

Vzhledem k možnostem a rozsahu článku zde nejsou uvedena témata, která by mohla zvolenou problematiku rozvinout a popsat podrobněji (např. negativní vliv hudby, vztah hudby a církve $v$ historických souvislostech, aktivně provozovaná hudba atd.). Rovněž chybí zpracování významného a širokého tématu, jakým je oblast liturgické hudby, zhudebnění a zpěv žalmů ad. Zajímavá by též byla aplikace na konkrétní praktické príklady.

\section{Hudba}

Hudba a zpěv provázejí lidstvo od jeho počátků. Existují teorie, které tvrdí, že zpěv a zpěvní projev ovládal člověk daleko dříve než počátky mluvy. ${ }^{1}$ Zpěv a hudba jsou fenomény, které nalézáme všude tam, kde jsou lidé. Hraje nezastupitelnou roli v životě člověka, provází ho od dětství až do konce života. ${ }^{2}$

Přestože slovem hudba může každý jednotlivec označit něco jiného, hudební věda tímto termínem v současném pojetí označuje systém zvuků, který je organizovaný. To, jakým způsobem dochází k výběru těchto zvuků, k jejich rytmickému členění a uspořádání, určuje pak kvalitu, funkci a estetické působení ${ }^{3}$ hudby. ${ }^{4} \mathrm{Na}$ základě historického vývoje pojmu hudba a tím, jak je hudba definována v současnosti, můžeme naznačit tři okruhy, které hudba vyjadřuje. Hudba je umění vycházející a zároveň působící na emoce člověka. Hudba je chápána ve spojitosti se společenstvím, má tedy svou sociální dimenzi. Hudba je nositelem duchovní myšlenky, a jako taková má tedy svůj duchovní rozměr. ${ }^{5}$ "Hudba obsahuje dva prvky: akustický materiál a duchovní myšlenku. Obojí nestojí jako forma a obsah izolovaně vedle sebe, nýbrž se v hudbě spojuje do uceleného tvaru (...). Jelikož se hudba realizuje zvukem, je nejpřiměřenější interpretací hudby interpretace znějící. Smyslový a duchovní prožitek hudby se stupňuje spojením emocí, fantazie a síly zážitku. ${ }^{\text {6 }}$

\footnotetext{
1 Ch. Darwin soudil, že zpěv byl prvním dorozumívacím prostředkem, který předcházel řeči. Poukazoval na podobnou funkci ptačího zpěvu. V nedávné době tuto teorii rozvíjel např. skladatel O. Messiaen.

2 Ještě dříve, než se dítě umí verbálně vyjádřit, sděluje své pocity pomocí své „vokální kapacity“.

3 Srov. (C) Centrum hudební lexikografie, Český hudební slovník osob a institucí (on-line), dostupné na: http:/ /www.ceskyhudebnislovnik. cz/slovnik/index.php?option=com_mdictionary\&action=list_letter\&letter=h\#idxhu, citováno dne 23. 8. 2014.

4 Termín hudba, resp. muzika, a jeho chápání se v průběhu dějin lišil, postupuje od starověkého matematicko-esteticko-filosofického pojetí přes eticko-výchovnou funkci až k pojetí dnešnímu. Blíže viz např. Jaroslav SMOLKA, Dějiny hudby, Brno: TOGGA, 2001.

5 Srov. Miloš SCHNIERER, nepublikované přednášky z Hudební estetiky, Č. Budějovice: Konzervatoř, 1999.

6 Ulrich MICHELS, Encyklopedický atlas hudby, Praha: Nakladatelství Lidové noviny, 2000, s. 11.
} 


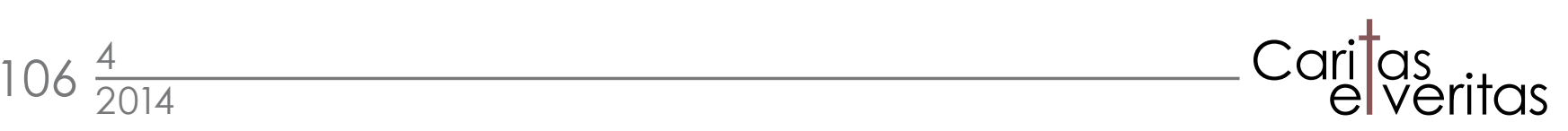

Kromě toho, že hudba může přispívat sama o sobě k hlubšímu poznávání člověka, je také důležitým prostředkem sebereflexe lidské existence ve světě. Hudba může být jakýmsi prostředkem vyjádření ve vztahu k transcendentnu. Tak jak je verbální řeč schopna oznámit a vyjádřit racionálně pochopitelný obsah, tak je hudba schopna oznamovat a podávat rozumově nepochopitelné až v konečném důsledku nevypověditelné skutečnosti. S trochou nadsázky můžeme říci, že tam, kde končí slova, začíná zpěv a hudební projev. Hudba a zpěv, kromě celé řady dalších funkcí, ${ }^{7}$ také zaujímá zvláštní místo v dialogu člověka s Bohem. ${ }^{8}$ Od svých počátků byla hudba postavena do vztahu s náboženstvím. Přesto ale nemusí být takto chápaná hudba hudbou náboženskou (v užším smyslu). Podobně jako náboženství snaží se i hudba přiblížit nevyslovitelnému: beze slov, ale přece jinou řečí, řečí zvuků. ${ }^{9}$ Hudba také slouží k vyjadřování nesmyslových, duševních a duchovních souvislostí. „Kde se člověk setkává s Bohem, tam si totiž už s pouhou řečí slov nevystačí. Probouzejí se ty oblasti jeho existence, které se samy stávají zpěvem. " ${ }^{10}$ Konstituce Gaudium et spes naznačuje důležité a vznešené poslání hudby. "Tím, že se člověk věnuje různým oborům, jako je filosofie, historie, matematika a přírodní vědy, a zabývá se uměním, může velkou měrou přispět $\mathrm{k}$ tomu, aby se lidská rodina povznesla k vyšším pojmům pravdy, dobra a krásy a k obecně platnému nazírání, a byla tak dokonaleji osvícena podivuhodnou Moudrostí, která byla u Boha od věčnosti, všechno s ním pořádala, hrála si na okruhu země a bylo jí rozkoší stýkat se s lidmi. Tím se také může lidský duch, více uvolněný z poroby věcí, snadněji povznést k uctívání Stvořitele a k nazírání na něho. “11

Díky různým formám umění lze převést do srozumitelnějších tvarů to, co je samo o sobě nevyslovitelné. Umění musí totiž učinit pochopitelným svět ducha, svět neviditelného, svět Boha. Právě hudba je schopna zachytit různé aspekty tohoto poselství a převést je do tónů, akordů, harmonií a melodií, které povzbudí intuici posluchače. ${ }^{12}$ Hudba může být vnímána také jako jistý druh symbolického jazyka. Je hlasem, který neoslovuje zvukem jen smysly, ale uchvacuje také mysl a zasahuje srdce. Na rozdíl od mluveného slova je hudba univerzálním jazykem. ${ }^{13}$

Některá hudební sdělení (především hudba vokální) jsou, díky zhudebněnému textu, nositelem snadno pochopitelného, mimohudebního obsahu (významu) skladby. Celá řada hlubokých textů písní, ale i nejrůznějších skladeb o pozitivních hodnotách života a víře v Boha se může stát obrovským přínosem při hudebních produkcích. V určitých žánrech nás může text (nebo i jiné mimohudební složky) informovat o různých tématech, která jsou umocněna jejich hudebním zpracováním. Na druhou stranu se nám však může jevit text a jeho přínos v hudbě jako indiferentní. Bez problému můžeme poslouchat vokální hudbu v cizím, pro nás nesrozumitelném jazyce, přičemž nerozumíme kognitivní informaci nebo významu textu, a přesto nás

\footnotetext{
7 Zjednodušujícím způsobem můžeme rozdělit hudbu a zpěv do následujících čtyř oblastí, ze kterých jsou pak odvozovány její funkce: 1. oblast estetického působení hudby - je postavena na prožitku pocitu „krásna“, jedná se o individuální záležitost, která je závislá na individuálním vkusu, preferenci určitých hudebních žánrů a stylů, kdy se umělecká hodnota skladby nemusí rovnat estetické hodnotě (napřs. i hudba amatérsky podaná může u některých posluchačů vyvolat estetické zážitky, přestože umělecká hodnota nebude vysoká, a platí to i naopak); 2. oblast terapeutického působení hudby - kromě muzikoterapie apod. sem patří např. i návštěva koncertu za účelem odreagování či odpočinku; 3. oblast výchovného a vzdělávacího působení hudby; 4. oblast rituálního působení hudby - kromě kultické či liturgické hudby sem patří i hudba světská (promoce, občanské svatby), ale např. i návštěva technopárty apod.

8 Již př́rodní náboženství využívala hudbu k ovlivnění božstev. Izraelité se k Bohu obracejí pomocí hudby a zpěvu při jeho chválení, zvěstování jeho činů a prosbě o požehnání. Hudbu chápou jako vhodný prostř̌edek k odpovědi člověka, který je adresátem Božího sdílení. Křestáané od nejstarších dob pak pomocí hudby vzývají a oslavují Boha. Liturgická hudba se postupem doby stala výrazným prostředkem v dialogu s Bohem. Bliže viz František KUNETKA, Stručné dějiny hudby a zpěvu v liturgii, Olomouc: Matice cyrilometodějská, 1999.

9 Srov. Peter Paul KASPAR, Musica sacra: Das grosse Buch der Kirchenmusik, Graz, Wien, Köln: Verlag Styria, 1999, s. 7.

10 Josef RATZINGER, Duch liturgie, Brno: Barrister \& Principal, 2006, s. 119.

11 Dokumenty II. vatikánského koncilu, Kostelní Vydři: Karmelitánské nakladatelství, 2002, Konstituce Gaudium et spes, čl. 57 (Víra a kultura), dále v textu pouze GS a číslo př́slušného článku.

12 Srov. @ JAN PAVEL II.: List umělcům (on-line), dostupné na: http://www.cirkev.cz/cirkev-ve-svete/dokumenty/hneda-rada/?page=3, citováno dne 18. 7. 2014.
}

13 Srov. Richard VILADESAU, Theology and the arts, Mahwah, New Jersey: Paulist Press, 2000, s. 38. 
takový poslech a vnímání hudby může velmi výrazně oslovit a obohatit. Se slovem nesvázaná hudba představuje ryzí spiritualitu. ${ }^{14}$

T. Akvinský, když odpovídá na námitku, že při zpěvu může docházet k neporozumění textu, říká: „I když někteří nerozumějí tomu, co se zpívá, přece chápou, proč se zpívá, totiž k Boží chvále. A to stačí k povznesení člověka k zbožnosti. "

Mnohokrát se stalo biblické slovo hudbou (nebo jakýmkoliv dalším uměním), což představuje v dějinách kultury rozsáhlou kapitolu víry a krásy. „Pro všechny však, věřící i nevěřící, zůstávají umělecká díla inspirovaná Písmem odleskem neproniknutelného tajemství, které zahaluje a naplňuje svět." ${ }^{16}$ „Existuje celá řada takových lidí, kteří sami dokážou lépe zpívat srdcem než ústy, ale jimž zpívání těch, kterým je to dáno i ústy, skutečně může rozezpívat srdce, takže jako by sami zpívali v těch druhých, a vděčné slyšení spolu se zpíváním zpěváků se tak stávají jedinou Boží chválou. “"17

\section{Krása, hudlba, Bưh}

V dějinách estetiky vidíme, že problém rozdělení krásy byl řešen různými způsoby. Někteří autoři (těch je nejvíce) dělili krásu na základě přirozených kategorií věcí, které jsou krásné. Rozlišovali pak, v podstatě shodně, ale s různými odchylkami, krásu nekonečnou (Bůh) a krásu konečnou (tvorové), krásu konečnou dělili na nemateriální a materiální, materiální krásu na krásu přírody a na krásu uměleckou atd. S takovým dělením se setkáváme nejen ve starověku a středověku, ale také v novověku.

V následujícím textu není chápáno slovo krása jako termín označující krásným to, co uspokojuje smysly („smyslová krása“), ale jako termín, který by se dal vyjádřit jako krása převyšující smysly. Estetismus, který považuje umění za vlastní cíl s jeho vlastními měřítky, je neslučitelný s biblickou předlohou, která požaduje od umění i jistou služebnost. ${ }^{18}$

K objevení a přijetí Boha je výsostně důležitá cesta krásy, protože krása patří k nejhlubší Boží podstatě. Proto Bůh vtiskl do člověka schopnosti, jak vyjádřit i to, co je tajemné a nesdělitelné. Ŕ́káme tomu dar umění, jeden ze sedmi darů Ducha svatého. Kdybychom jej podcenili nebo zanedbali, ochudili bychom sami sebe a naše snaha o evangelizaci by postrádala jeden důležitý rozměr a zůstala by chudá a bezbarvá. ${ }^{19}$

Vztah mezi dobrým a krásným může vyvolat řadu podnětných úvah. Krása je v jistém smyslu viditelným obrazem dobra, tak jako je dobro podmínkou krásy. Po celý středověk byl živým tématem protiklad mezi vnější a vnitřní krásou. Nehynoucí vnitřní krása je totiž jedinou zárukou tváří v tvář pomíjivosti vnější krásy. Vnímání krásy či krásna středověkým člověkem má spoustu aspektů. Středověký člověk okamžitě obrací cit pro krásno v pocit společenství s Bohem. Má-li být krásno skutečnou hodnotou, pak se musí shodovat s dobrem, s pravdou a se všemi dalšími atributy bytí a božství. Dále je pro středověkého člověka velmi těžké nazírat

\footnotetext{
14 Srov. Albert GERHARDS, Im Spannungsfeld von Wort und Zeichen, in: Musik im Raum der Kirche, Stuttgart: Carus-Verlag, 2007, s. 52-55. 15 Josef RATZINGER, K teologickému základu liturgické hudby, Salve 2/2008, s. 21.

16 (C) List papeže Jana Pavla II. umělcům.

17 Josef RATZINGER, K teologickému základu liturgické hudby, s. 22.

18 Srov. (C) Josef RATZINGER, Bohu zpívejte umělecky (on-line), dostupné na: http://www.sdh.cz/sdh_htm/odjinud/zpivejte_um.htm, citováno dne 14. 7. 2014.

19 Srov. Josef HRDLIČKA, Rozhlasové pořady o duchovní hudbě na Radiu Proglas.
} 


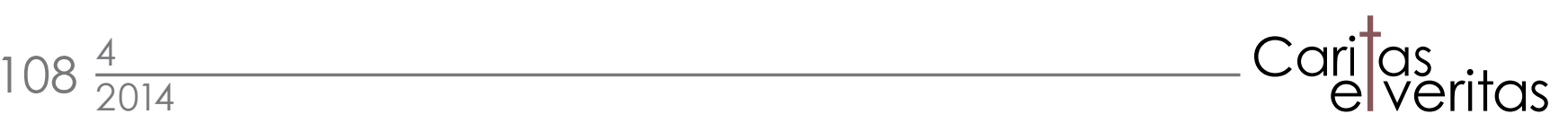

hodnotu krásy a užitečnosti odděleně. Scholastika ve 13. století si vytvořila pojem transcendentálních vlastností, tj. obecných vlastností bytí. Tradičně byly jako transcendentálie chápány unum - jedno, jednota; verum - pravda; bonum - dobro a další. Vznikl problém, zda lze krásno rovněž chápat jako transcendentálii či nikoli. Bylo-li by krásno stálou vlastností veškerého bytí, pak by se krása kosmu nezakládala na prostém poetickém pocitu, nýbrž na metafyzické jistotě. Problém chápání krásna jako transcendentálie vyvolal nutnost definovat, za jakých specifických podmínek může být bytí nazíráno jako krásné. Filosofie tedy v určitém okamžiku začala pocit'ovat potřebu kriticky se zabývat problémem estetiky. Objevují se různé názory na krásno i pokusy je definovat. Napřr. Vilém z Auvergne (francouzský teolog a filosof, † asi 1249) ř́íká, že smyslově vnímatelná krása je to, „co se líbí tomu, kdo ji vidí“20, vnitřní krása je to, co budí zalíbení v duši toho, kdo ji vytuší a je ochoten ji milovat. Dobro, které nacházíme v lidské duši, označujeme jako krásu analogicky k vnější a viditelné kráse. Robert Grosseteste (anglický teolog a filosof, † 1253) uvádí svou definici krásna v závislosti na dobru. „Je-li tedy všem věcem společné to, že tíhnou k dobru a krásnu, pak dobro a krásno jsou jedno a totéž. “21

Dobro je podle něj Božím jménem proto, že uděluje věcem existenci a uchovává je v bytí, zatímco krásno je Božím jménem proto, že se stává př́ičinou uspořádávající stvoření. ${ }^{22}$ Krása je transcendentálií i u sv. Tomáše. „Krásno a dobro v podmětu jsou sice totéž, poněvadž stojí na téže věci, totiž na tvaru, a proto dobro se chválí jako krásno. Ale v rozumu se liší. Nebot' dobro se vlastně vztahuje na touhu; jest totiž dobro, po čem všechno touží. A proto má ráz účelu, nebot' touha jest jako nějaký pohyb k věci. Krásno však se vztahuje ke schopnosti poznávací; krásným totiž se jmenuje to, co spatřeno se líbí. “23 A na jiném místě: „Krásno jest totéž s dobrem, jen rozumem odlišné. Ježto totiž dobro jest, co každý žádá, v pojmu dobra jest, aby v něm spočinula žádost. Ale k pojmu krásna patří, aby ve spatření či poznání jeho se ukojila žádost, proto též ony smysly obzvláště se týkají krásna, které jsou nejvíce poznávací, totiž zrak a sluch, rozumu sloužící; ř́íkáme totiž ,krásná na pohled' a ,krásné zvuky'. U poznaných pak jinými smysly neužíváme jména krásy; nebot' neříkáme ,krásné chuti nebo vưně’. A tak jest patrné, že krásno přidává nad dobro nějaké zařízení k síle poznávací; tak, že dobrem se nazývá to, co jednoduše se líbí žádosti, krásnem pak se nazývá to, čeho postřeh sám se líbí.“ ${ }^{24}$

Krása je poslední slovo, které si myslící intelekt může dovolit vyslovit, nebot' tím korunuje nepostižitelné nádhery, dvojitou hvězdu pravdy a dobra a jejich nerozdělitelného vztahu. ${ }^{25}$ V souvislosti s Krásnem stojí za pozornost zmínit i vybraná oslovení Boha v Ježíši Kristu. „Ty jsi krása... Tys krása!" - takto nazývá Boha sv. František z Assisi ve svém chvalozpěvu poté, co obdržel Kristova stigmata. To komentuje sv. Bonaventura slovy: „Kontemploval v krásných věcech Nejkrásnějšího a jda po stopách vtisknutých do tvorů, nacházel všude Milovaného." ${ }^{26}$ Ve východní spiritualitě je Kristus označován jako „nejkrásnější ze všech smrtelníků“.27 Sv. Augustin jako člověk, který byl zamilovaný do krásy, ř́ká: „Pozdě jsem si tě zamiloval, kráso tak starobylá a tak nová, pozdě jsem si tě zamiloval!“28

\footnotetext{
20 Umberto ECO, Umění a krása ve středověké estetice, Praha: Argo, 1998, s. 41.

21 Tamtéž, s. 42.

22 Srov. tamtéž s. 35-45.

23 (C) Tomáš AKVINSKÝ, Summa Theologica I q. 5 a. 4 ad 1 (on line), dostupné na: http://summa.op.cz/sth.php?\&A=4, citováno dne 28. 10. 2014.

24 Tamtéž, I-II q. 27 a. 1 ad 3.

25 Srov. Hans Urs von BALTHASAR, Herrlichkeit, Eine thelologische Ästhetik, Frankfurt: Johannes Vlg., 1988, s. 4-15.

26 Srov. (C) List papeže Jana Pavla II. umělcům.

27 Srov. tamtéž.

28 Srov. tamtéž.
} 
Nejen uvedení světci, ale každý člověk poznávající svět si všímá jeho krásy. Písmo svaté hovoří jasně o tom, že Bůh je původcem krásy. V Knize moudrosti čteme: „Vskutku nicotní jsou od př́rody všichni lidé, kterým nebylo dáno znát Boha. Ze všeho dobrého, co mají před očima, nedokázali poznat toho, který je, a z pohledu na dílo nerozpoznali Tvůrce. Ale oheň, vítr nebo rychlý mrak, hvězdný kruh, dravé vodstvo nebo nebeská světla považovali za světovládné bohy. Jestliže unesení jejich krásou je pokládali za bohy, tím spíše měli poznat, oč lepší je jejich Pán, nebot' on, té krásy Prapůvodce, vše stvořil." (Mdr 13,1-3) Přínosné pro uvažování o kráse jako o cestě vedoucí k Bohu jsou myšlenky Jana Pavla II. vyjádřené v Listu umělcưm. Pro něj, stejně jako pro autory biblických knih, je samozřejmé, že „krása pochází od Boha a člověk ji odhaluje a ve svých dílech napodobuje, přičemž zvláštní úloha spočívá v pưsobení umělců... Krása je znamením tajemství a připomínkou transcendence. Je pobídkou k vychutnání života a snění o budoucnosti. Právě proto nemůže krása stvořených věcí přinést uspokojení a vzbuzuje onu tajuplnou tesknotu po Bohu. “29 Cesta krásy a umění je jednou z možných cest k duši člověka - ale není cestou nijak samozřejmou a všeobecně přístupnou. Je náročná v odkrývání krásy a ve formaci, která umožňuje porozumět poselství krásy.

O cestě krásy jako jedné z možných cest vedoucích k Bohu a jejím možném využití při hlásání evangelia hovoří již papež Jan Pavel II. i jeho nástupci Benedikt XVI. a papež František. Via pulchritudinis (Cesta krásy) je také název závěrečného dokumentu plenárního sněmu Papežské rady pro kulturu z roku 2006. Z názvu je zřejmé, že se dokument zabývá cestou krásy jako vhodnou cestou pro evangelizaci a dialog. Via pulchritudinis vnímá jako prostředníka mezi naší via crucis, která je přeměněna v Kristu do jeho via lucis. Umělecké dílo není samo o sobě „krásou“, ale je výrazem nevyslovitelného tajemství Boha. Proto je krása vnímána jako něco, co přesahuje estetické vnímání a vede až k nalézání ztělesnění Boha. Umělecká díla inspirovaná křest́anskou vírou (hudební skladby, malby, architektura atd.) mohou při vhodném využití umožnit setkání s Bohem ve zkušenosti víry. Proto je žádoucí vést lidi k chápání jazyka krásy, aby byli schopni chápat poselství křest'anského umění. ${ }^{30}$

V kontextu tématu textu se v následující části budeme zabývat estetickou stránkou hudby a jejího estetického vlivu z pohledu posluchače či návštěvníka koncertu. Na tuto problematiku bude nahlíženo také na základě výše uvedených tezí se snahou poukázat na poslech a chápání hudby jako na jednu z forem via pulchritudinis. Stranou zůstane celá řada dalších důležitých aspektů, které mohou být s estetickou funkcí hudby spjaty (např. interpret, skladatel, prostor ad.). Dále nás bude zajímat poslech hudby v různých souvislostech a schopnost naslouchat (hudbě). Právě umět naslouchat a chápat hudební sdělení umožňuje zprostředkovávat ono krásné, neuchopitelné, nesdělitelné poselství hudby, které může vnímavého posluchače nasměrovat k Bohu.

Vnímání hudby a vztah k hudební produkci lze vnímat i z pohledu estetického. ${ }^{31}$ Můžeme hovořit o estetickém osvojování hudby. Termín osvojování chápeme v tomto případě jako aktivní sluchovou recepci (apercepci) hudebně-zvukového osvětí člověka i vytváření nového umělého hudebního prostředí schopného nést estetické i praktické funkce. K estetickému osvojování hudby dochází v procesu vnímání hudby jak v kontextu historicko-společenském, tak i indivi-

29 Tamtéž.

30 Srov. (C) The Via Pulchritudinis, concluding document of the plenary assembly (on-line), dostupné na: http://www.vatican.va/roman curia/pontifical_councils/cultr/documents/rc_pc_cultr_doc_20060327_plenary-assembly_final-document_en.html, citováno dne 28. 10. 2014.

31 Hudební estetično je znějící hudbě přisouzená terciální vlastnost krásy nebo jiné působivosti (dokonalosti, vznešenosti, př́ijemnosti...), která vyvolává v posluchači pocit libosti, který vede k požadavku opakovaného navození této libosti. V případě autora (skladatele) navozuje tato libost pocit tvưrčího uspokojení. 


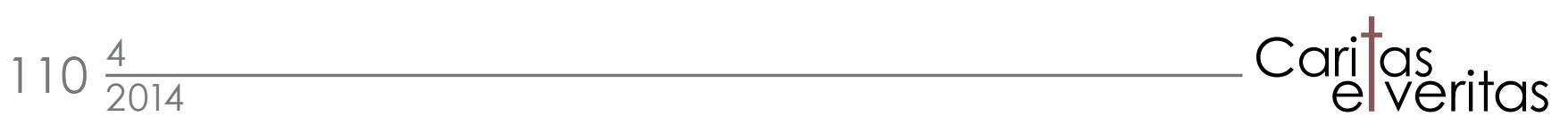

duálním. Toto osvojení má podobu jak tvưrčí, skladatelskou, tak posluchačskou. Posluchačské osvojení je označováno jako recepce hudby (Z. Lisa) ${ }^{32}$ či hudební apercepce (I. Poledňák) ${ }^{33}$. I v těchto př́ípadech jde o vysoce aktivní činnost. Můžeme poukázat na určitou analogii aktivního poslechu hudby s požadavkem aktivní účasti slavení liturgie, jak je uvedena v Sacrosanctum Concilium jako jedna z dalších forem slavení liturgie: „Ve vhodných chvílích se má také zachovávat posvátné mlčení. “" Aktivní účastí se zde nechápou pouze vnější projevy jednotlivce, ale právě i poslouchání (naslouchání), vnímání, přijímání smysly i duchem. Zrovna tak posluchač hudebního poselství, který je hudbou osloven, musí vynaložit určité úsilí, být aktivní, přestože se navenek neprojevuje žádným zpơsobem. Bez citlivého sluchu a bez vnímavé, předem připravené mysli by posluchači tu sebekrásnější hudbu jako „krásnou“ neslyšeli. ${ }^{35}$

Budeme-li uvažovat hudebně-esteticky o problematice „hudebních hodnot“ , můžeme konstatovat, že hudební hodnoty jsou relativní, mohou mít platnost jen v rámci určité doby, daného typu či vrstvě společnosti. I když jsou hudební útvary přenositelné časově i geograficky, nemusí být nutně přenosné i ve smyslu hodnotovém, tedy jako díla s uměleckou nebo estetickou působivostí. Hudba je totiž produktem společnosti, a ta sdílí historicky proměnlivá hudebně hodnotová měřítka. Gnozeologie hudby, jako jedna z oblastí zkoumání hudby, se zabývá historicky proměnlivými lidskými možnostmi hudbu poznat a pochopit, eventuálně s pomocí hudby poznat a pochopit i něco mimo ni samotnou. ${ }^{36}$

Když je někdo nakloněn vnímání hudby - je schopen dekódování a interpretace uměleckého sdělení -, nemusí to nutně znamenat, že je schopen umělecké dílo pochopit. Rozumět nebo chápat „něco“ znamená vyznat se ve věci, dokázat se v ní orientovat. Míra pochopení se však neurčuje podle množství pochopeného, ${ }^{37}$ ale podle podstatné významnosti. Podstatně významné není to, jestli hudbou se zabývající jedinec (posluchač, interpret) rozumí nějakému jazyku, znakovému systému (zná notovou soustavu) a na základě toho dokáže správně reagovat na pokyny jiného uživatele tohoto jazyka, systému - je schopen přehrát, přečíst skladbu z notového zápisu. To, že danému jazyku rozumí, ještě neznamená, že chápe smysl sdělení. Podstatné pro (po)rozumění (dekódování) a chápání uměleckého díla (hudební skladby) je "vidět" do věci, znát smysl, vědět, proč dílo vzniklo, chápat konkrétní dílo jinak - zahrál, interpretoval bych je jinak, promítat vlastní pocity a prožitky do díla. ${ }^{38}$ Pochopíme-li smysl hudebního sdělení, můžeme je teprve „efektivně“ esteticky prožít. Pokud tomu tak není, tak nasloucháme, ale neslyšíme.

V této souvislosti je ale potřeba ještě doplnit jeden aspekt, který hraje velmi důležitou roli při chápání uměleckého sdělení (hudby) a duchovních jevi̊, a to je cit. Duchovní jevy (i umění) nemohou být plně pochopeny jen rozumem, ale musejí být také prožity. ${ }^{39}$ "Posluchač tím, že přináší svou vlastní náladu, může na hudbu nahlížet esteticky jako na umělecké dílo, nebo jako na hudební ztvárnění nějaké myšlenky, anebo ji prostě vnímat a nechat působit ,vlny

\footnotetext{
32 Srov. Jan VIČAR - Roman DYKAST, Hudebni estetika, Praha: AMU, 2002, s. 28.

33 Srov. tamtéž

34 Dokumenty II. vatikánského koncilu, Kostelní vydří: Karmelitánské nakladatelství, 2002. Konstituce Sacrosanctum Concilium, čl. 30 (Aktivní účast věřících); dále v textu pouze SC a číslo příslušného článku.

35 Srov. Jan VIČAR - Roman DYKAST, Hudební estetika, s. 27-29.

36 Srov. tamtéž, s. 29-34.

37 Např. jestliže vím, že tóny, které slyším, jsou ve výši C1, E1 a G1, je mé pochopení jednodušší, než když si budu schopen uvědomit, že slyším intervaly velké a malé tercie. Ještě hlubší bude mé chápání, když si navíc uvědomím, že tyto intervaly jsou durovým kvintakordem, a když budu v kontextu vnímat tyto tóny jako tóniku tóniny $\mathrm{C}$ dur.

38 Srov. Jiří KULKA, Psychologie umění, Praha: Grada Publishing, a. s., 2008, s. 358-372.

39 Srov. tamtéž, s. 370-371.
} 
tónů. Může uchopit hluboce něco, co skladatel pocit'oval jen povrchně, může hledat myšlenky, kde žádné nejsou, a může shledat slabým mnohé, v čem se skrývá hluboký cit. ${ }^{40}$

Pro racionální i estetické pochopení hudebního díla mohou výrazně přispět znalosti z oblasti dějin hudby, hudební nauky, kontextu vzniku konkrétního díla a určitá "připravenost" posluchače („,angažovaný posluchač“). Poměrně rozsáhlou skupinou „konzumentů“ hudby (at” už jsou to návštěvníci koncertů různých žánrů nebo lidé, kteří hudbu poslouchají pomocí nejrůznějších technických zařizení a hudebních nosičů) tvoří lidé bez hudebního vzdělání či lidé bez jakékoliv "přípravy" pro poslech hudby. A přesto i v takových situacích je hudba schopna jedince zasáhnout, oslovit, zaujmout a promlouvat k němu. „Možná je někdy neskonale lepší nevědět o hudbě vůbec nic, než mít jen polovičaté znalosti, jakými oplývají snobové." ${ }^{41}$ Kromě výše uvedených způsobů vnímání a působení hudby můžeme ještě pracovat $s$ další možností - tzv. připravenou spontánností. Podle této teorie člověk sice nemůže přistupovat k poslechu hudby úplně nepoučen (stačí třeba určitá psychologická příprava), ale tyto přípravné fáze nemusí nutně narušit bezprostřednost kontaktu s hudbou.

Posluchač při aktivním poslechu vyhodnocuje dosavadní a anticipuje další průběh hudební skladby a provádí její vlastní restrukturaci a estetickou interpretaci. Je limitován a ovlivněn svými hudebními vědomostmi, zkušenostmi a potřebami. Je zřejmé, že hodnocení a pocit jednotlivce po doznění konkrétní skladby bude velmi individuální. Na druhou stranu je možné, že toto vnímání bude podobné či stejné jako u jiných posluchačů. Při vnímání hudby má posluchač mnoho individuálního, co charakterizuje jen jeho samotného, i mnoho společného s ostatními posluchači. „To všechno dohromady vytváří onu příznačnou směsici sdíleného zážitku krásy v jejích tisících individuálních specifikacích, který se vyskytuje u podobně hudebně citlivých a poučených návštěvníků veřejných koncertů a vtiskuje těmto produkcím neopakovatelnou atmosféru jedinečnosti. “42

\section{Preevangelizace}

Pro potřeby následujícího textu ponechme stranou diskuzi nad otázkou, zda vůbec potřebuje hlásání evangelia nějakou formu preevangelizace. Přidržme se vysvětlení tohoto pojmu, tak jak je popsán v apoštolské exhortaci Pavla VI. (1975). ${ }^{43}$ Toto chápání přejímá i Plenární sněm katolické církve v ČR (2005). ${ }^{44}$

Preevangelizace (tj. předběžná evangelizace) je první a počáteční evangelizací, kterou provádí církev. I tato preevangelizace je však již ve skutečnosti evangelizací, třebaže jen v počátečním a dosud neúplném stupni. Při preevangelizaci se uplatňuje téměř nekonečná řada různých prostředků, mezi nimiž má jistě své místo kázání, ale mimo to i umění, etická výchova, vědecká průprava, filosofický výzkum a oprávněné působení na city lidského srdce. Ačkoliv toto prvotní hlásání evangelia je určeno zvláště pro ty, kdo dosud nikdy neslyšeli o Kristově radostné zvěsti (anebo dětem), je zřejmé, že tento způsob je nutný i proto, že dnešní svět se často odkřest'anštujuje - je mnoho lidí, kteří byli pokřtěni, ale vůbec nežijí křest́ansky. ${ }^{45}$ Preevangelizace tedy

\footnotetext{
40 Friedrich NIETZSCHE, Rané texty o hudbě a řeči, Praha: OIKOYMENH, 2011, s. 122.

41 Ernst Hans GOMBRICH, Př́běh umění, Praha: Argo, 1999, s. 29.

42 Jan VIČAR - Roman DYKAST, Hudební estetika, s. 64

43 Srov. PAVEL VI., Evangelii Nuntiandi, Praha: Zvon, 1990, č. 51, 52.

44 Srov. Život a poslání křestáanů v Církvi a ve světě (Závěrečný dokument Plenárního sněmu katolické církve v ČR), Kostelní Vydří, 2007, s. 114.

45 Srov. PAVEL VI., Evangelii Nuntiandi, č. 51, 52.
} 
začíná nabídkou okruhů všelidského zájmu, společného věřícím i nevěřícím, dále pak ochotou být s nimi a jejich řečí připravovat půdu pro radostnou zvěst.

V kontextu předchozího textu můžeme termín preevangelizace chápat také jako rozvoj přirozených, kulturních a morálních hodnot ve společnosti. Preevangelizace vytváří prostor pro to, aby se dalo evangelizovat. Znamená též budování pozitivního postoje k morálním hodnotám důležitým pro společnost a odbourávání předsudků vůči církvi.

Současný papež František poukazuje ve své apoštolské exhortaci Evangelii gaudium (2013), ${ }^{46}$ která je zaměřena na hlásání evangelia v současném světě, také na „cestu krásy“ (via pulchritudinis) ${ }^{47}$ a umělecké vyjádření při hlásání evangelia. Tyto formy označuje za nový jazyk podobenství.

Zvěstovat Krista, dle tohoto textu, znamená ukazovat, že věřit v něj a následovat jej není jenom něco pravého a správného, ale také krásného, schopného dát životu nový lesk a hlubokou radost i uprostřed zkoušek. V této perspektivě mohou být všechny výrazy autentické krásy rozpoznány jako cesta napomáhající setkání s Pánem Ježíšem. Nejde o estetický relativismus, který může zatemňovat nedělitelné pouto mezi pravdou, dobrem a krásou, ${ }^{48}$ nýbrž o obnovení úcty ke kráse s cílem dospět k lidskému srdci a dát v něm zazářit pravdě a dobrotě Vzkřišeného. Je-li tomu tak, jak praví sv. Augustin, že totiž nemilujeme než to, co je krásné, pak Syn učiněný člověkem - zjevení nekonečné krásy - je svrchovaně hoden lásky a přitahuje nás k sobě poutem lásky. Je tedy nutné, aby součástí předávání víry byla formace vycházející z via pulchritudinis. Je žádoucí, aby každá místní církev ve svém evangelizačním pưsobení podporovala využívání umění $\mathrm{v}$ návaznosti na bohatství minulosti, ale také $\mathrm{v}$ šíři jeho rozmanitých současných výrazů, aby se tak víra předávala novou „ř̌ečí v podobenstvích“. ${ }^{49}$ Je zapotřebí odvahy nalézat nová znamení, nové symboly, nové tělo pro předávání Slova, různé formy krásy, které se objevují v rozličných kulturních prostředích, včetně oněch nekonvenčních modalit krásy, které mohou být málo významné pro hlasatele evangelia, ale staly se zvlášt přitažlivé pro druhé..$^{50}$

Jan Pavel II. ve své promluvě k účastníkům Mezinárodního kongresu církevní hudby nastiňuje jako jednu z možností využití (náboženské) hudby při (pre)evangelizačním úsilí: „Náboženská hudba staví mosty mezi poselstvím spásy a všemi, kteří Krista ještě zcela a úplně nepřijali, jsou však vnímaví pro krásu, nebot' krása je znamením tajemství a připomínkou transcendence. Krása umožňuje plodný dialog. ${ }^{\text {51 }}$

46 Srov. FRANTIŠEK, Evangelii gaudium (Radost evangelia), Praha: Paulínky, 2014.

47 Cesta krásy (via pulchritudinis) - takto také ve svých promluvách označuje Benedikt XVI. cestu (formu), která je schopna vést mysl i srdce do věčnosti, pozdvihnout je až do Božích výšin. Cesta krásy je zároveň uměleckým, estetickým přístupem a cestou víry a teologického hledání. Cesta krásy vede k chápání Celku ve zlomku, Nekonečného v tom, co je konečné, Boha v dějinách lidstva.

48 Podobným způsobem apeluje ve své promluvě k umělcům Benedikt XVI.: „Hledání krásy, o které mluvím, evidentně nespočívá v útěku do iracionálna nebo pouhého estetismu. Příliš často je však propagovaná krása iluzorní a lživá, mělká a oslňující, ba omračující, a namísto toho, aby dala lidem vyjít ze sebe, otevřela je k horizontům pravé svobody a přitáhla vzhůru, uvězňuje je v nich samotných a ještě více je zotročuje, zbavuje naděje i radosti. Jde o svůdnou a pokryteckou krásu, která budí žádostivost, vůli po moci, majetku a utiskování druhého..." srov. (C) BENEDIKT XVI. promluva k umělcům „Umělec je strážcem krásy“ (on-line), dostupné na: http://www.radiovaticana.cz/clanek. php4?id=12066, citováno dne 16. 11. 2014.

49 Některé překlady používají termín: „novým ,parabolickým jazykem““. Sousloví odkazuje k promluvě Benedikta XVI., kterou pronesl při projekci filmového dokumentu „Arte e fede - via pulchritudinis“. Jazyk umění je jazykem podobenství (možná lépe - odkaz na vyklenutí vysokého oblouku v originální „parabole“), jehož zvláštností je všeobecná přístupnost.

50 Srov. FRANTIŠEK, Evangelii gaudium (č. 167), s. 106, 107.

51 (C) JAN PAVEL II., Promluva k účastníkům mezinárodního kongresu církevní hudby (on-line), dostupné na: http://www.sdh.cz/sdh_ htm/archiv/promluvy.htm\#nahoru, citováno dne 28. 10. 2014. 
Hudba při využívání nových katechumenálních cest nabízí možnosti svobodného tvưrčího setkání v „předsíni“ křest'anského společenství a jeho hlásání evangelia. Hudba, především duchovní, může být vnímána jako jeden z prostředků, skrze který můžeme být osloveni slovem Božím. ${ }^{52}$

Když hledáme odpovědi na otázku, jakým způsobem seznámit společnost (děti, mladé lidi i dospělé) s Ježíšem Kristem takovým způsobem, aby poznávali jeho osobu, jeho poslání a směřovali k němu, je potřeba všímat si způsobů vyjadřování a komunikace dnešní společnosti. Díky velkému rozvoji nejrůznějších technických prostředků je řada lidí v současné době zvyklá obklopovat se hudbou téměř nepřetržitě. Tato přemíra hudby, která přechází až v jakýsi "hudební smog", může způsobit, že člověk bude ztrácet dosavadní typ hudebně-estetické vnímavosti. Medializace hudby vede k určité devalvaci dosavadních uměleckých hodnot a hudba se stává v některých vrstvách společnosti prostředkem k odpoutání se od vnějšího světa, zvukovou kulisou i „drogou“. Proto je žádoucí promýšlet a doporučovat k poslechu vhodné interprety, skladatele a možnosti poslechu hudby (účast na koncertech apod.). Nejde jen o to akcentovat hudbu, která by posluchače nějakým způsobem zaujala, ale snažit se poukazovat na takovou hudbu, jejíž tvưrci skrze ni vyjadřují svůj vztah k Bohu. ${ }^{53}$

Na základě předchozího textu můžeme pak konstatovat, že takováto hudba se může stát „kazatelnou“, skrze kterou může církev promlouvat k lidem. M. Luther dokonce označoval náboženskou hudbu jako „zvučné kázání“. Nezabývá se ale hudbou jako nositelkou textu, nýbrž jako zrcadlem Boží krásy. Hudba, dle něj, může oslovit duši informací o Bohu v situacích, kdy to nelze vyjádřit slovy. ${ }^{54}$ Skrze hudbu, která je inspirována křest'anskou vírou, „podivuhodným zpo̊sobem vnímáme krásu, která nám umožňuje zakoušet Boží přítomnost někdy působivěji než kázání. Hudba spojená s katechezí pak hlásá krásu, transcendentální krásu, která přesahuje hranice rozumu a zkušenosti, a proto nemůže být ničím jiným než krásou vnitřní. Tak se projevuje Bůh ve své nádheře a ve své slávě a poukazuje na neviditelné, tak jako Syn viditelně ukazuje na neviditelného Otce. ${ }^{\prime 55} \mathrm{Na}$ základě uvedeného můžeme uvažovat i o jakési misionářské funkci hudby. Pozornost liturgické hudbě při misijním poslání dokládá i text v konstituci Sacrosanctum Concilium. „V některých územích, zvláště misijních, jsou národy s vlastní hudební tradicí; ta má velký význam pro jejich náboženský a sociální život. Této hudbě náleží patřičná vážnost a přiměřené místo jak při utváření náboženského cítění těch národů, tak při přizpůsobování liturgie jejich národní povaze..."56

O tom, že si církev byla a stále je vědoma významu a důležitosti hudby nejen při liturgických obřadech, svědčí celá řada nařízení a dokumentů, které se problematikou hudby, především té liturgické, zabývají. Už od počátku se zdůrazňoval jako důležitý úkol církevní hudby služba bližnímu, výchova věřících ve smyslu listů sv. Pavla $($ Ko 3,16): „....se vší moudrostí se navzájem učte a napomínejte a s vděčností v srdci oslavujte Boha žalmy, chválami a zpěvem..." S tímto požadavkem koresponduje text papeže Pia X.: „Posvátná hudba jakožto nedílná (integrální) část slavné liturgie má s ní společný všeobecný cíl, totiž slávu Boží a posvěcení i vzdělání věřících..." ${ }^{47} \mathrm{~V}$ nejstarším zachovaném předpisu o církevní hudbě od sv. papeže Řehoře (595)

52 Srov. Maeve Louise HEANEY, Music as theology, Eugene, Or.: Wipf and Stock Publishers, 2012, s. 130-135.

53 Nejedná se „pouze“ o liturgickou hudbu - tedy o hudbu, která slouží k doprovodu liturgie, nebo se sama stává součástí liturgie. Máme na mysli hudbu, která je inspirována náboženstvím - úctou k Bohu a svatým, Biblí, liturgií a životem církve. Jde jak o oblast artificiální hudby, tak o oblast nonartificiální hudby.

54 Srov. Richard VILADESAU, Theology and the arts, s. 34.

55 Pavel ŠUPOL, Křestán a hudba, Brno: Kartuziánské nakladatelství, 2010, s. 54.

56 SC 119

57 Srov. @ P PIUS X., Motu proprio "Tra le sollecitudini“ (on-line), dostupné na: http://www.sdh.cz/sdh_htm/archiv/mo_pro.htm, citováno dne 28. 9. 2014. 


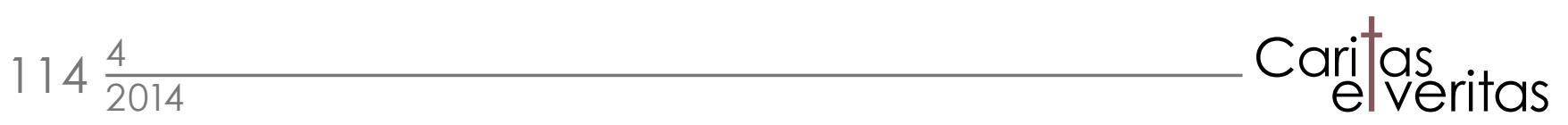

se dočteme: „Kantor musí zpívat s dobrým názorem, když chce vychovávat lid." 58 Většina církevních nařízení a dokumentů se zabývá vztahem hudby a liturgie. Církevní hudba je v těchto textech chápána především v užším slova smyslu - jako liturgická hudba, kterou se koná liturgie (mše, denní modlitba církve, svátosti a svátostiny). Jsou to zhudebněné texty, lidové duchovní písně a jejich instrumentální doprovody, předehry, mezihry a dohry. „Je to ta hudba, která je komponována pro slavení bohoslužby a vyznačuje se posvátností a krásou formy..." ${ }^{59}$ Pro chápání a porozumění této problematice by bylo potřeba popsat a promýšlet další příčiny, souvislosti a motivy, což už stojí mimo tematiku tohoto příspěvku. Pro základní orientaci je v poznámce uveden zjednodušený přehled církevních dokumentů a textů, které se liturgickou hudbou zabývají. ${ }^{60}$

\section{Závěr}

Vývoj evropské hudby je spojený s křest́anstvím. Děje se tak jak po stránce obsahové a tematické, tak i v rovině teoretické. Hudba naplněná křest'anskými ideami dokáže někdy více zapůsobit na mysl a city lidí než jen samotné verbální projevy. ${ }^{61}$ Hudební díla inspirovaná křest’anstvím představují výjimečnou část hudebního a kulturního dědictví.

Taková hudební sdělení, jak jsme popsali výše, mohou otevírat a rozšiřovat horizonty lidského vědomí a odkazovat nad ně samotné. Estetické působení hudby je postaveno na individuálním prožitku pocitu krásna. Je to znějící hudbě přisouzená vlastnost krásy.

Proto jsme se dále zaměřili na oblast krásy a zabývali se krásnem $\mathrm{v}$ kontextu tématu. Konfrontovali jsme krásno a dobro a na základě předložených tezí můžeme konstatovat, že krása je v jistém smyslu viditelným obrazem dobra, tak jako je dobro podmínkou krásy. O kráse, která pochází od Boha a vzbuzuje onu tajuplnou touhu po Bohu, se hovoří v souvislosti s cestou krásy (via pulchritudinis). Tato cesta krásy může nabídnout jednu z možností (pre) evangelizace.

Byla zmíněna i schopnost umět naslouchat a pochopit (chápat) hudbu. To je jedna z důležitých podmínek pro poslechové hudební aktivity. Učit se naslouchat hudebnímu sdělení znamená též vést posluchače k vnímání ticha. Vztah hudby a ticha nespočívá jen v protikladu, který tvrdí: Ticho je absence hudby. Díky schopnosti naslouchat tichu jsme naopak schopni vnímat jednotlivé tóny, které se z ticha vynořují a zase se do něho vracejí. Pro vnímání a poslech hudby je tedy důležitá zkušenost naslouchání a ticho může být klíčem ke zkušenosti se zvukem.

Přestože rozsah práce i vymezení v úvodu neumožňuje uvést konkrétní praktické př́iklady, které by byly zajímavým doplněním předkládaných myšlenek, závěrem stručně uvedeme jeden ilustrativní př́iklad.

\footnotetext{
58 Peter Paul KASPAR, Musica sacra: Das grosse Buch der Kirchenmusik, s. 35.

59 @ Instrukce Musicam Sacram čl. 4 (on-line), dostupné na: http://www.sdh.cz/sdh_htm/archiv/mus-sac.htm, citováno dne 28. 10.2014.

60 Základní předpisy katolické církve, které se týkají liturgické hudby od počátku 20. století: motu proprio Pia X. „Tra le sollecitudini“ o posvátné hudbě (1903); apoštolská konstituce Pia XI. „Divini cultus sanctitatem“ (1928); encyklika Pia XII. „Musicae sacrae disciplina“ (1955); instrukce o církevní hudbě a posvátné liturgii (1958); SC, 6. kapitola „De musica sacra“ (1963); instrukce „Musicam Sacram“ (1967); Všeobecné pokyny k římskému misálu (1970); instrukce k správnému provádění liturgické konstituce „Inter Oecumenici“ (1964), ,"Tres abhinc annos“ (1967), „Liturgicae Instaurationes“ (1970).

61 Srov. Ferdinand KLINDA, Křest'anstvo a hudba na Slovensku, Kultúra 18/2003, s. 15.
} 


\section{Gregoriánský chorál}

Je to liturgický, latinský jednohlasý zpěv bez doprovodu nástrojů. ${ }^{62}$ Tento zpěv považovala a považuje katolická církev za svůj vlastní zpěv, který byl brán jako vzor a ideál pro liturgickou hudbu. Pro široké masy lidí dnešní doby se gregoriánský chorál stává zajímavou poslechovou hudební alternativou. Kromě autentického zpěvu se gregoriánský chorál stává (jako tomu bylo po staletí jeho existence) i inspirací pro hudební řeč dnešní doby. A to jak v oblasti artificiální hudby, tak v oblasti hudby nonartificiální. Muzikologické disciplíny připisují tento úspěch tomu, že jde o jednoduchý, melismatický zpěv bez pravidelného rytmického členění a mimo tonalitu dur a moll (chorál vyžívá tzv. [církevních] modů). Zjednodušeně řečeno: Chorál nabízí posluchači úplně jiný druh hudby, než na který je zvyklý z rádia, televize..., a to ho nutí naslouchat a vnímat tuto hudbu jinak. Nepoučený posluchač vůbec nemusí vědět, že jde o liturgický zpěv, o text, který vyzpívává nejrůznější aspekty náboženského a liturgického života a vztah k Bohu. A přesto je v lidstvu zakořeněna představa spojení chorálu s chrámem, mnišstvím, církví, ale také s mystičnem apod. Chorál, kromě své rituální funkce (jako liturgická hudba), může plnit i funkci estetickou (koncertní provedení), má funkci výchovně-vzdělávací (jako odborný předmět - zkoumání kompoziční techniky a náboženského života konkrétní doby) a může mít též funkci terapeuticko-psychohygienickou (domácí poslech a relaxace) ad. Všechny tyto aspekty a další symboly se dají využít a pomocí průniků jednotlivých oblastí je s nimi možné pracovat při koncertech, hudebních pořadech či vytváření hudebních nahrávek. Přestože poslání chorálu nebylo nikdy církví chápáno jen jako estetické zhudebnění slova či vytváření relaxačních skladeb pro terapeutické účely, může to být ona „nekonvenční modalita krásy“, o které hovoři papež František, která je málo významná pro hlasatele evangelia, ale která může být zvlášt' přitažlivá pro druhé. Jeho slova můžeme chápat také tak, že není nutné používat to, co je zažité, nestavět jen na minulém (liturgicky chápaný chorál), ale jsou zde i pozitivní skutečnosti, které nebyly (nejsou) využívány (komentovaný koncert gregoriánského chorálu, ukázky skladeb inspirovaných chorálem...).

Gregoriánský chorál přes hudbu renesance, baroka a velkou polyfonii žije z vnitřního bohatství syntézy ducha, intuice a smyslového zvuku i v plnosti těchto možností. "Velikost“ a hloubka této hudby je spojena s možností vyrůstat $\mathrm{z}$ antropologického základu, kde se spojovalo duchovní s profánním v jednotu lidství. Hudba, která je schopna naplnit výzvu „vzhưru srdce“, musí nějakým způsobem integrovat smysly do ducha, ale nemůže být ,jen“ čistým zduchovněním. Mělo by jít o takové spojení smyslů a ducha, ve kterém se obojí stává osobností. Pokud by totiž při hudební produkci fungovala pouze smyslová rozkoš, kterou nelze zvyšovat donekonečna, nastalo by po určité době zklamání. A právě díky integraci v duchu dostanou smysly novou hloubku a mohou sahat až do duchovního nekonečna. Takto uchopená hudba se stává očistou člověka a jeho vzestupem. ${ }^{63}$

Aby mohla být hudba považována za jeden z aspektů preevangelizace, neměla by být chápána jen jako prostředek pro seberealizaci a exhibování některých umělců. Taková hudba totiž ztratí svoji schopnost rozechvívat struny našeho srdce, rozšiřovat naši duši, a tím se snáze obracet k Bohu.

Velikost této hudby spočívá dle J. Ratzingera v tom, že je nejbezprostřednější a nejpřesvědčivější verifikací křest'anské víry ve spásu, kterou nám historie nabízí. Koho si taková hudba

62 Blíže viz např. Jaroslav SMOLKA, Dějiny hudby, Brno: TOGGA, 2001.

63 Srov. @ Josef RATZINGER, Světský a lidský obraz a jeho odraz v liturgické hudbě, Bonum, Verum, Pulchrum, roč. II., 2, 3, 4/2009 (on-line), dostupné na: https://sites.google.com/site/bovepul/archiv/roc-ii-c-2-3-4-2009/svetsky-a-lidsky-obraz-a-jeho-odraz-v-liturgicke-hudbe, citováno dne 22. 8. 2014. 


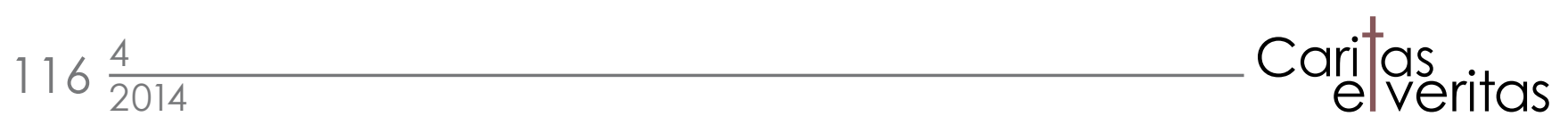

podmaní, ten již ve svém nitru ví, že víra je pravá, přestože potřebuje ještě mnoho kroků $\mathrm{k}$ tomu, aby tento pocit upevnil i rozumem a vưlí.

\section{Hudba jako jeden z možných aspektů preevangelizace}

Abstrakł Článek pojednává o vztahu hudby a náboženství. V textu je popsána estetická funkce hudby a její teologicko-filosofický základ. Ve zvolené oblasti je poukázáno na využití poslechu hudby jako jedné $z$ forem preevangelizace. Téma je řešeno $v$ kontextu církevních dokumentů a koresponduje s vnímáním a funkcí hudby $v$ církvi.

Klíčová slova hudba; estetika; preevangelizace

\section{Music as a Possible Aspect of Pre-Evangelization}

Abstract The paper deals with the relationship of music and religion. The text describes the aesthetic function of music and its theological-philosophical foundation. In the selected sphere the paper points out the use of listening to music as a form of pre-evangelization. The topic is discussed in the context of Church documents and corresponds to the perception and function of music in the Church.

Keywords music; aesthetics; pre-evangelization 